CLINICAL STUDY

\title{
Acute exogenous TSH administration stimulates leptin secretion in vivo
}

Ferruccio Santini ${ }^{1}$, Giulia Galli ${ }^{1}$, Margherita Maffei $^{2}$, Paola Fierabracci $^{1}$, Caterina Pelosini ${ }^{1}$, Alessandro Marsili $^{1}$, Monica Giannetti ${ }^{1}$, Maria Grazia Castagna ${ }^{3}$, Serenella Checchi ${ }^{3}$, Eleonora Molinaro ${ }^{1}$, Paolo Piaggi ${ }^{4}$, Furio Pacini ${ }^{3}$, Rossella Elisei ${ }^{1}$, Paolo Vitti ${ }^{1}$ and Aldo Pinchera ${ }^{1}$

${ }^{1}$ Department of Endocrinology and Kidney and ${ }^{2}$ Dulbecco Telethon Institute at Department of Endocrinology and Kidney, University Hospital of Pisa, Via Paradisa, 2, 56124 Pisa, Italy, ${ }^{3}$ Department of Internal Medicine, Endocrinology and Metabolism, and Biochemistry, University of Siena, 53100 Siena, Italy and ${ }^{4}$ Department of Electrical Systems and Automation, University of Pisa, 56127 Pisa, Italy

(Correspondence should be addressed to F Santini; Email: fsantini@endoc.med.unipi.it)

\begin{abstract}
TSH-receptor (TSHR) has been found in a variety of cell types, including preadipocytes and adipocytes. In vitro, TSH-mediated preadipocyte and adipocyte responses include proliferation, differentiation, survival, and lipolysis.

Objective: To measure the response of serum leptin to exogenous administration of recombinant human TSH (rhTSH) in vivo.

Patients: One hundred patients with differentiated thyroid cancer already treated by total thyroidectomy and ${ }^{131}$ I remnant ablation were enrolled. Mean ( \pm s.E.M.) body mass index (BMI) was $26.9 \pm 0.6 \mathrm{~kg} / \mathrm{m}^{2}$.

Methods: Patients received a standard dose of rhTSH for measurement of thyroglobulin in the follow-up of their disease. Blood samples were taken for the assay of TSH and leptin before the first administration of rhTSH (time 0), and $24 \mathrm{~h}$ (time 1), $48 \mathrm{~h}$ (time 2), $72 \mathrm{~h}$ (time 3), and $96 \mathrm{~h}$ (time 4) after the first administration of rhTSH.

Results: Significant mean serum leptin increments, with respect to basal value, were 16, 13, 18, and $11 \%$ at times 1, 2, 3, and 4 respectively. Significant positive correlations of leptin-area under the curve with respect to basal leptin levels $(r=0.43 ; P<0.0001)$ and BMI $(r=0.32 ; P<0.005)$ were observed. Conclusions: Acute rhTSH administration in hypothyroid subjects under L-thyroxine therapy produces a rise in serum leptin. This increase is proportional to the adipose mass suggesting that a functioning TSHR is expressed on the surface of adipocytes. The role that TSHR activation in adipocytes might play in physiological and pathological conditions remains a matter of investigation.
\end{abstract}

European Journal of Endocrinology 163 63-67

\section{Introduction}

The TSH-receptor (TSHR) is expressed on the surface of follicular thyroid cells, but mRNA and protein have been reported in a variety of cell types, including preadipocytes and adipocytes (1).

High affinity TSH binding activity of Graves' IgG has been shown in guinea pig adipocytes (2-4), and Tshr cDNA fragments have been obtained by PCR from rat or human retro-orbital tissues, adipose tissue, and fibroblasts (5-8). In vitro studies indicate that TSH-mediated responses on adipocytes include proliferation, differentiation, survival, and stimulation of specific cellular pathways (9-17). In vitro studies with rat or human visceral adipocytes reveal opposite effects of TSH on leptin secretion. In rat epididymal adipocytes, TSH inhibited basal (18) and insulin-stimulated (19) leptin secretion. By converse, in a systematic study of organ cultures of human omental adipose tissue,
TSH powerfully stimulated leptin secretion in vitro, while prolactin, ACTH, FSH, and LH were devoid of action (14).

This study was designed to test whether acute administration of recombinant human TSH (rhTSH) to thyroidectomized patients is followed by changes in serum leptin concentrations, which would imply that the TSHR is functionally active in human adipocytes in vivo.

\section{Patients and methods}

One hundred consecutive patients (77 females and 23 males) turning to our Endocrine Unit were enrolled after total thyroidectomy and 131-iodine remnant ablation for differentiated thyroid cancer. Patients were scheduled to receive rhTSH (Thyrogen Genzyme, Cambridge, MA, USA) for diagnostic purposes. Clinical, hematological, and instrumental examinations of each 
Table 1 Age and body mass index (BMI) of the study group expressed as mean values \pm S.E.M. and range.

\begin{tabular}{lccc}
\hline & Total & Females & Males \\
\hline Age (years) & $47 \pm 1.3(16-76)$ & $47.9 \pm 1.4(20-73)$ & $45.8 \pm 3.3(16-76)$ \\
BMl $\left(\mathrm{kg} / \mathrm{m}^{2}\right)$ & $26.9 \pm 0.6(17.4-62.4)$ & $26.7 \pm 0.8(17.4-62.4)$ & $27.3 \pm 0.8(19.4-32.8)$ \\
\hline
\end{tabular}

patient were performed following the appropriate protocol for management of their disease. The study was approved by the Institutional Reviewing Board. Age and body mass index (BMI) of patients are shown in Table 1. Patients were on variable doses of L-thyroxine $\left(\mathrm{T}_{4}\right)$, from substitutive to suppressive. Each patient received a standard dose of $0.9 \mathrm{mg}$ rhTSH i.m. for two consecutive days according to the conventional protocol (20). Blood samples were taken between 0800 and $0900 \mathrm{~h}$ after an overnight fasting for the assay of TSH and leptin, before the first administration of rhTSH (time 0), and $24 \mathrm{~h}$ (time 1), $48 \mathrm{~h}$ (time 2), $72 \mathrm{~h}$ (time 3), and $96 \mathrm{~h}$ (time 4) after the first administration of rhTSH. All patients attended for routine follow-up.

Serum TSH was measured using a solid-phase, twosite chemiluminescent immunometric assay (Immulite 2000, Third Generation TSH, Los Angeles, CA, USA; analytical sensitivity, $0.004 \mu \mathrm{U} / \mathrm{ml}$; intra-assay coefficient of variation, $<12 \%$; linearity $85-104 \%$ ). Serum leptin was measured by IRMA (Active Human Leptin IRMA, DSL-23100i, Webster, TX, USA; analytical sensitivity, $0.10 \mathrm{ng} / \mathrm{ml}$; intra-assay coefficient of variation, $<5 \%$; linearity $80-110 \%$ ).

A time-average analysis of baseline-corrected serum leptin and TSH concentrations (area under the curve, $\mathrm{AUC}_{4}$ days) was performed. One-way repeated measures ANOVA was conducted to compare serum leptin concentrations at various time points. Post-hoc comparisons were conducted using Bonferroni's correction when necessary. A mixed between-within subjects ANOVA was also conducted in order to evaluate the effect of gender on leptin serum concentrations during time. Simple linear regression analysis was applied when indicated. Statistical significance was defined as $P<0.05$. Data are presented as mean \pm s.E.M.

\section{Results}

Mean values of basal TSH did not show a significant difference between females $(0.5 \mu \mathrm{U} / \mathrm{ml} \pm 0.2$, range $0.003-6.5 \mu \mathrm{U} / \mathrm{ml})$ and males $(0.5 \mu \mathrm{U} / \mathrm{ml} \pm 1.21$, range $0.003-3.6 \mu \mathrm{U} / \mathrm{ml})$.

After rhTSH administration, a wide spectrum of values of serum TSH was observed. As expected (20), the TSH-AUC 4 days was significantly lower in males (215.8 $\mu \mathrm{U} / \mathrm{ml} \times \mathrm{d} \pm 14.6$, range 96.3-418.5) than in females $(275.5 \mu \mathrm{U} / \mathrm{ml} \times \mathrm{d} \pm 12$, range $68.8-718.7)$. TSH-AUC 4 days was negatively related to BMI $(r=0.26, P<0.05)$ and positively associated with age $(r=0.27, P<0.05)$.
The values of serum leptin at several time points after rhTSH administration are reported in Table 2. A significant difference in serum leptin concentrations (Wilks' $\lambda=0.82, F=5.824, P<0.005$, multivariate partial $\eta^{2}=0.18$ ) by one-way repeated measures ANOVA was observed. Post-hoc comparisons using the Bonferroni's correction indicated that the mean serum leptin concentration at time 0 was significantly different from that at time $1(P<0.001)$, time $2(P<0.05)$, time $3(P<0.005)$, and time $4(P<0.05)$. A mixed betweenwithin subjects ANOVA was conducted to explore the impact of gender and time on serum leptin concentrations. There was a statistically significant main effect for time (Wilks' $\lambda=0.886, F=3.064, P<0.05$, multivariate partial $\left.\eta^{2}=0.11\right)$ and for gender $(F=8.138$, $P<0.01$, multivariate partial $\left.\eta^{2}=0.07\right)$ with females showing higher mean values of serum leptin concentrations than males. The gender-time interaction effect did not reach statistical significance. Since distribution of basal serum leptin concentrations spanned a broad range, we have assessed the TSH-induced increase in serum leptin within groups of subjects identified by quartiles of serum leptin at time 0. Results are shown in Fig. 1. Although not always reaching statistical significance (due to the low number of subjects in each group), a clear increase is observed in each quartile.

A linear positive correlation between serum leptin at time 0 and BMI was observed in the total population $(r=0.75 ; P<0.0001)$, in females $(r=0.81 ; P<0.0001)$, and in males $(r=0.43 ; P<0.05)$.

The mean value of leptin-AUC 4 days in the total population was $6.2 \pm 1.5 \mathrm{ng} / \mathrm{ml} \times \mathrm{d}$, being higher in females $(7.1 \pm 1.9 \mathrm{ng} / \mathrm{ml} \times \mathrm{d})$ than in males $(3.3 \pm 1.3 \mathrm{ng} / \mathrm{ml} \times \mathrm{d})$.

Table 2 Values of serum leptin $(\mathrm{ng} / \mathrm{ml})$ at several time points after recombinant human TSH (rhTSH) administration expressed as mean \pm S.E.M., and percent variation (\%) with respect to leptin at time 0 .

\begin{tabular}{lccr}
\hline & $\begin{array}{c}\text { Total } \\
\text { population }\end{array}$ & Females & \multicolumn{1}{c}{ Males } \\
\hline Time 0 & $11.6(100) \pm 1.1$ & $13.3(100) \pm 1.3$ & $5.9(100) \pm 0.9$ \\
Time 1 & $13.5(116) \pm 1.3$ & $15.4(116) \pm 1.6$ & $7.1(120) \pm 1.1$ \\
Time 2 & $13.1(113) \pm 1.3$ & $14.9(112) \pm 1.6$ & $7(119) \pm 1.1$ \\
Time 3 & $13.7(118) \pm 1.5$ & $15.8(119) \pm 1.8$ & $6.4(109) \pm 0.9$ \\
Time 4 & $12.9(111) \pm 1.3$ & $14.7(111) \pm 1.6$ & $6.9(117) \pm 1.1$ \\
\hline
\end{tabular}

One-way repeated measures ANOVA in the total population, $P<0.05$. Significant differences after post-hoc Bonferroni's correction: time 0 versus time $1(P<0.001)$, time $2(P<0.05)$, time $3(P<0.005)$, and time $4(P<0.05)$. A mixed between-within subjects ANOVA showed a statistically significant main effect for time $(P<0.05)$ and for gender $(P<0.01)$. 

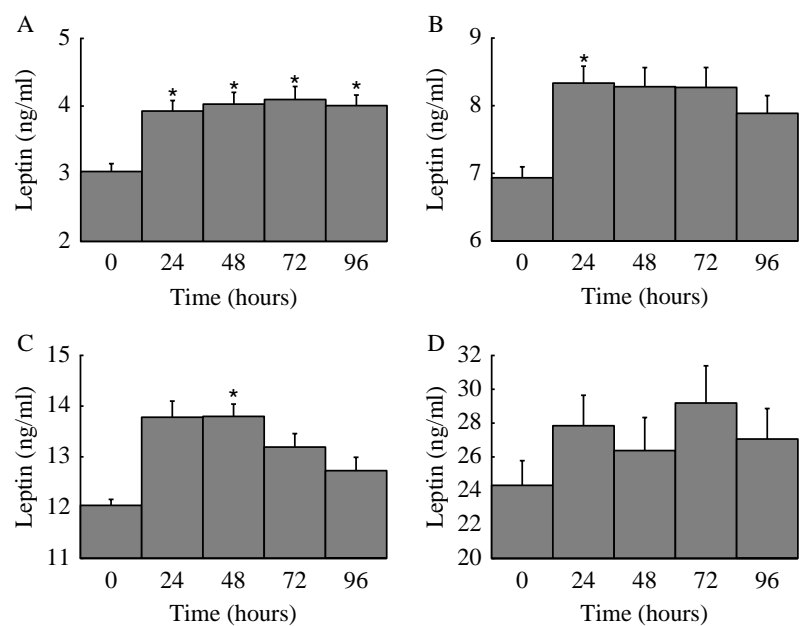

Figure 1 Serum leptin concentrations before the first administration of rhTSH (time 0), and 24 (time 1), 48 (time 2), 72 (time 3), and 96 (time 4) hours after the first administration of rhTSH. Subjects were divided according to quartiles of serum leptin at time 0 : first quartile $(A)$, second quartile (B), third quartile (C), and fourth quartile (D). Data are shown as mean and S.E.M. Results were analyzed by one-way repeated measures ANOVA. ${ }^{*} P<0.05$ after post-hoc Bonferroni's correction versus time 0 .

Serum leptin- $\mathrm{AUC}_{4}$ days was positively associated with serum leptin at time 0 (Fig. 2A) in the total population as well as in females and in males, separately. A significant positive correlation between serum leptin-AUC and BMI (Fig. 2B) in the total population and in females was also observed. No significant association between serum $\mathrm{TSH}_{-} \mathrm{AUC}_{4}$ days and serum leptin- $\mathrm{AUC}_{4}$ days was observed.

\section{Discussion}

Leptin is a hormone produced mainly by adipocytes that acts on specific neurons within well-defined centers, by relaying information regarding the level of energy stored in the adipose tissue. Leptin participates in the regulation of energy homeostasis, and serum leptin concentrations are proportional to the total fat mass. Hormones and nutrients may influence leptin gene expression or regulate translational efficiency and mRNA stability (21-24).

Data herein presented show that acute rhTSH administration produces a significant increase in serum leptin concentrations in vivo. This model has been previously used to demonstrate an increase of bone remodeling markers in humans, suggesting that TSH can modulate bone remodeling independent of thyroid hormones (25).

The TSH-induced increase in serum leptin may have biological relevance in two areas: the in vivo demonstration of a functional TSHR on the surface of human adipocytes and the potential role of TSH in the control of leptin secretion. The increase in serum leptin concentrations was proportional to BMI and basal serum leptin concentrations, both indices of the total adipose mass. These relationships suggest that the adipose tissue is responsible for the TSH-induced elevation of serum leptin and strongly supports the occurrence of an active TSHR on adipocytes. Yet, the possibility of an indirect effect of TSH via the receptors expressed in the pituitary or brain (1) cannot be ruled out. Whether rhTSH effect on serum leptin persists beyond the length of this study cannot be established at this time, since blood sampling was stopped at $96 \mathrm{~h}$ after the first rhTSH administration, according to the standard protocol for thyroglobulin measurement in thyroid cancer patients. In a recent study, no significant variations in serum leptin concentrations after in vivo stimulation with rhTSH were reported (26). The small number of subjects and different times of observation of TSH effects might explain the lack of significant changes in serum leptin observed in that study.

The action of the thyroid axis components on leptin secretion has been previously investigated. However, no data has demonstrated in a definitive way that thyroid dysfunction affects circulating leptin, and that the minor leptin changes occasionally observed might be explained by parallel alterations in body weight of the subjects under observation. In particular, serum leptin in hypothyroid patients has been found lower, higher, or
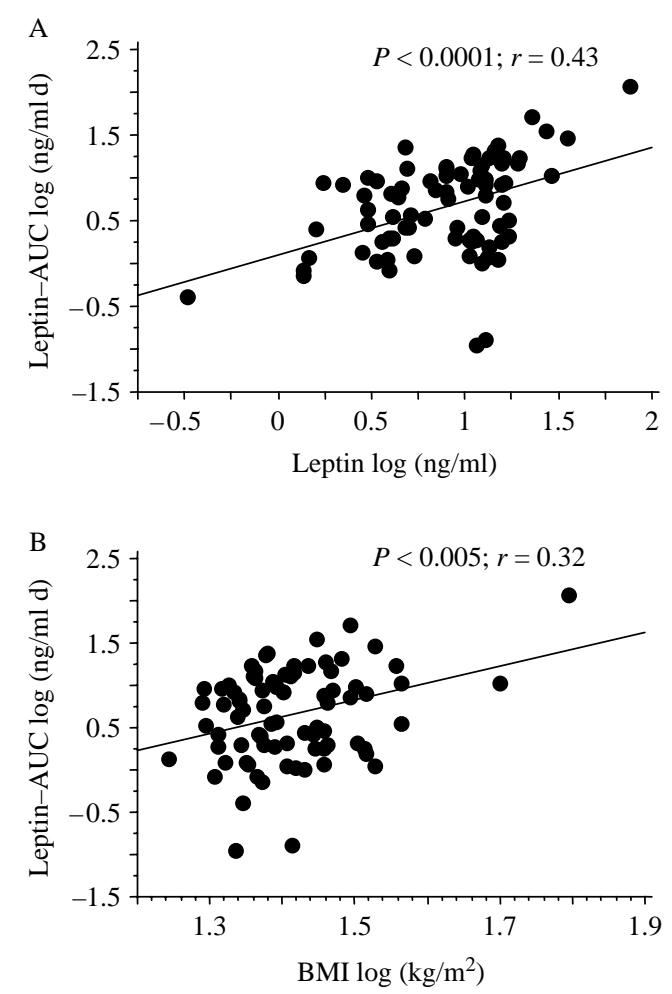

Figure 2 Correlations between baseline-corrected serum leptin$\mathrm{AUC}_{4}$ days after rhTSH administration and serum leptin at time $0(\mathrm{~A})$, and $\mathrm{BMI}(\mathrm{B})$. 
unchanged, compared with euthyroid subjects (27-35). It should be noted that in primary hypo- and hyperthyroidism, conflicting effects on leptin secretion and/or clearance could be exerted by simultaneous opposite changes in serum thyroid hormones and TSH, which may result in incoherent variations of serum leptin concentrations. Furthermore, in protracted critical illness such as severe hypo- and hyperthyroidism, additional mechanisms beside thyroid hormone and TSH may intervene in the regulation of leptin secretion. The balance between free and bound leptin might have an impact since the free hormone is the one that selectively represents the fat mass (36), and this might explain the conflicting results obtained when measuring total leptin in the majority of the studies of thyroid patients. Another explanation for the lack of leptin changes in primary hypothyroidism is that the latter condition is characterized by chronically elevated serum TSH that may not necessarily generate a measurable effect on leptin secretion, at variance with what we observed after an acute stimulation. Finally, the discrepancies observed among various studies may be related to the presence of TSHR antibody in serum of patients with autoimmune thyroid disease. This autoantibody, by directly activating TSHR or by inhibiting TSH action, could produce a confounding effect on TSHmediated regulation of leptin secretion. However, in this regard, no correlation between serum leptin concentrations and the title of TSHR antibody has been reported in patients with Graves' disease (37).

Based on our results, we cannot infer about a role of TSH on the adipocyte function in physiological or pathological conditions, and no evidence currently allows us to define the relationship and possible mechanisms of mutual adjustment between leptin and TSH. It could be speculated that TSH-induced changes of leptin secretion may concur to modulate the feeding behavior observed in hypo- and hyperthyroidism. We believe that a leptin-mediated effect of TSH on appetite is unlikely since leptin changes induced by TSH are modest compared with the magnitude of appetite changes observed in thyroid dysfunction. However, it is worthwhile observing that leptin action is not limited to appetite regulation. Indeed, recent evidence, obtained through positron emission tomography (PET) imaging, indicates that in both rodents and primates bone marrow and kidney represent major sites for leptin uptake (38).

Mostly important, in our view, is the support given by our results to the existence of a functioning TSHR on the surface of adipocytes, with regards to the pathogenesis of some extrathyroidal manifestations of autoimmune thyroid disease. These receptors, when bound by specific autoantibody, could play a major role in the development of thyroid-associated ophthalmopathy (TAO), a feature of Graves' disease characterized by an increased volume of adipose/connective tissue within the orbit (39). The initiation of TAO has been postulated to depend on the expression of TSHR in orbital preadipocytes (40). Orbital fibroblasts subjected to adipocyte differentiation increase TSHR expression in vitro, and the receptor is able to respond specifically to TSH and TSH antibody (41). Although the pathogenesis of TAO remains largely unknown, binding of TSHR antibody to TSHR seems to play a major role.

In conclusion, our study indicates that acute rhTSH administration in hypothyroid subjects under $\mathrm{L}^{-\mathrm{T}_{4}}$ therapy produces a rise in serum leptin. This increase is proportional to the adipose mass suggesting that a functioning TSHR is expressed on the surface of adipocytes. The role that TSHR activation in adipocytes might play in physiological and pathological conditions remains a matter of investigation.

\section{Declaration of interest}

F Pacini is a member of the Advisory Board for Genzyme and recipient of speaker's fees.

\section{Funding}

This study was supported by Ministero dell'Università e della Ricerca, programmi di ricerca scientifica 2007, 'Pathogenic mechanisms determining the obese phenotype and influencing the response to treatment'; Ministero della Salute, programmi di ricerca finalizzata 2006, 'Integrated protocols for the prevention and the treatment of obesity'.

\section{References}

1 Davies T, Marians R \& Latif R. The TSH receptor reveals itself. Journal of Clinical Investigation $2002 \mathbf{1 1 0} 161-164$.

2 Gill DL, Marshall NJ \& Ekins RP. Binding of thyrotropin to receptors in fat tissue. Molecular and Cellular Endocrinology 197810 89-102.

3 Loeffler M, Zakarija M \& McKenzie JM. Comparison of different of different assay for the thyroid-stimulating antibodies in Graves' disease. Journal of Clinical Endocrinology and Metabolism 198357 603-608.

4 Konishi J, Iida Y, Kasagi K, Ikekubo K, Kuma K \& Torizuka K. Adipocyte-TSH-receptor-relates antibodies in Graves' disease detected by immunoprecipitation. Endocrinology $1982 \quad 29$ 219-226.

5 Endo T, Ohno M, Kotani S, Gunji K \& Onaya T. Thyrotropin receptor in non-thyroid tissues. Biochemical and Biophysical Research Communications 1993190 774-779.

6 Feliciello A, Porcellini A, Ciullo I, Bonavolontà G, Avvedimento EV \& Fenzi G. Expression of thyrotropin-receptor mRNA in healthy and Graves' disease retro-orbital tissue. Lancet $1993 \mathbf{3 4 2}$ 337-338.

7 Heufelder AE, Dutton CM, Sarkar G, Donovan KA \& Bahn RS. Detection of TSH receptor RNA in cultured fibroblasts from patients with Graves' ophthalmopathy and pretibial dermopathy. Thyroid 19933 297-300.

8 Endo T, Ohta K, Haraguchi K \& Onaya T. Cloning and functional expression of a thyrotropin receptor cDNA from rat fat cells. Journal of Biological Chemistry 1995 270 10833-10837.

9 Haraguchi K, Shimura H, Lin L, Endo T \& Onaya T. Differentiation of rat preadipocytes is accompanied by expression of thyrotropin receptors. Endocrinology 1996137 3200-3205.

10 Rodbell M. Metabolism of isolated fat cells. Effect of hormones on glucose metabolism and lipolysis. Journal of Biological Chemistry $1964239375-380$. 
11 Bell A, Gagnon A, Dods P, Papineau D, Tiberi M \& Sorisky A. TSH signaling and cell survival in 3T3-L1 preadipocytes. American Journal of Physiology. Cell Physiology 2002283 C1056-C1064.

12 Haraguchi K, Shimura H, Kawaguchi A, Ikeda M, Endo T \& Onaya T. Effects of thyrotropin on the proliferation and differentiation of cultured rat preadipocytes. Thyroid $1999 \mathbf{9}$ 613-619.

13 Janson A, Rawet H, Perbeck L \& Marcus C. Presence of thyrotropin receptor in infant adipocytes. Pediatric Research $1998 \mathbf{4 3}$ 555-558.

14 Menendez C, Baldelli R, Camiña JP, Escudero B, Peino R, Dieguez C \& Casanueva FF. TSH stimulates leptin secretion by a direct effect on adipocytes. Journal of Endocrinology 2003176 7-12.

15 Bell A, Gagnon A \& Sorisky A. TSH stimulates IL-6 secretion from adipocytes in culture. Arteriosclerosis, Thrombosis, and Vascular Biology 200323 e65-e66.

16 Antunes TT, Gagnon A, Chen B, Pacini F, Smith TJ \& Sorisky A. Interleukin-6 release from human abdominal adipose cells is regulated by thyroid-stimulating hormone: effect of adipocyte differentiation and anatomic depot. American Journal of Physiology. Endocrinology and Metabolism 2006290 E1140-E1144.

17 Lu M \& Lin RY. TSH stimulates adipogenesis in mouse embryonic stem cells. Journal of Endocrinology 2008 196 159-169.

18 Shintani M, Nishimura H, Akamizu T, Yonemitsu S, Masuzaki H, Ogawa Y, Hosoda K, Inoue G, Yoshimasa Y \& Nakao K. Thyrotropin decreases leptin production in rat adipocytes. Metabolism $1999 \mathbf{4 8}$ 1570-1574.

19 Cammisotto PG \& Bukowiecki LJ. Mechanisms of leptin secretion from white adipocytes. American Journal of Physiology. Cell Physiology 2002283 C244-C250.

20 Castagna MG, Pinchera A, Marsili A, Giannetti M, Molinaro E, Fierabracci P, Grasso L, Pacini F, Santini F \& Elisei R. Influence of human body composition on serum peak thyrotropin (TSH) after recombinant human TSH administration in patients with differentiated thyroid carcinoma. Journal of Clinical Endocrinology and Metabolism 200590 4047-4050.

21 Zhang Y, Proenca R, Maffei M, Barone M, Leopold L \& Friedman JM. Positional cloning of the mouse obese gene and its human homologue. Nature 1994372 425-432.

22 Halaas JL, Gajiwala KS, Maffei M, Cohen SL, Chait BT, Rabinowitz D, Lallone RL, Burley SK \& Friedman JM. Weightreducing effects of the plasma protein encoded by the obese gene. Science 1995269 543-546.

23 Casanueva FF \& Dieguez C. Neuroendocrine regulation and actions of leptin. Frontiers in Neuroendocrinology 199920 317-363.

24 Lee MJ \& Fried SK. Integration of hormonal and nutrient signals that regulate leptin synthesis and secretion. American Journal of Physiology. Endocrinology and Metabolism 2009296 E1230-E1238.

25 Martini G, Gennari L, De Paola V, Pilli T, Salvadori S, Merlotti D, Valleggi F, Campagna S, Franci B, Avanzati A, Nuti R \& Pacini F. The effects of recombinant TSH on bone turnover markers and serum osteoprotegerin and RANKL levels. Thyroid 200818 455-460.

26 Cecoli F, Andraghetti G, Ghiara C, Briatore L, Cavallero D, Mussap M, Minuto F \& Giusti M. Absence of thyrotropin-induced increase in leptin levels in patients with history of differentiated thyroid carcinoma undergoing recombinant human thyrotropin testing. Journal of Endocrinological Investigation 200831 888-892.

27 Santini F, Marsili A, Mammoli C, Valeriano R, Scartabelli G, Pelosini C, Giannetti M, Centoni R, Vitti P \& Pinchera A. Serum concentrations of adiponectin and leptin in patients with thyroid dysfunctions. Journal of Endocrinological Investigation 200427 RC5-RC7.

28 Leonhardt U, Ritzel U, Schäfer G, Becker W \& Ramadori G. Serum leptin levels in hypo- and hyperthyroidism. Journal of Endocrinology 1998157 75-79.

29 Valcavi R, Zini M, Peino R, Casanueva FF \& Dieguez C. Influence of thyroid status on serum immunoreactive leptin levels. Journal of Clinical Endocrinology and Metabolism 199782 1632-1634.

30 Iacobellis G, Ribaudo MC, Zappaterreno A, Iannucci CV \& Leonetti F. Relationship of thyroid function with body mass index, leptin, insulin sensitivity and adiponectin in euthyroid obese women. Clinical Endocrinology 200562 487-491.

31 Owecki M, El Ali Z, Wasko R, Nikisch E, Dziubandowska A, Sulikowska A \& Sowiński J. Circulating leptin levels are not influenced by thyroid status in hypothyroid and euthyroid women. Neuroendocrinology Letters $2007 \mathbf{2 8} 417-421$.

32 Pinkney JH, Goodrick SJ, Katz JR, Johnson AB, Lightman SL, Coppack SW, Medbak S \& Mohamed-Ali V. Thyroid and sympathetic influences on plasma leptin in hypothyroidism and hyperthyroidism. International Journal of Obesity $2000 \mathbf{2 4}$ (Supplement 2) 165-166.

33 Pinkney JH, Goodrick SJ, Katz J, Johnson AB, Lightman SL, Coppack SW \& Mohamed-Ali V. Leptin and the pituitary-thyroid axis: a comparative study in lean, obese, hypothyroid and hyperthyroid subjects. Clinical Endocrinology 199849 583-588.

34 Corbetta S, Englaro P, Giambona S, Persani L, Blum WF \& Beck-Peccoz P. Lack of effects of circulating thyroid hormone levels on serum leptin concentrations. European Journal of Endocrinology $1997137659-663$.

35 Zimmermann-Belsing T, Brabant G, Holst JJ \& Feldt-Rasmussen U. Circulating leptin and thyroid dysfunction. European Journal of Endocrinology $2003149257-271$.

36 Brabant G, Horn R, von zur Mühlen A, Mayr B, Wurster U, Heidenreich F, Schnabel D, Grüters-Kieslich A, ZimmermannBelsing T \& Feldt-Rasmussen U. Free and protein bound leptin are distinct and independently controlled factors in energy regulation. Diabetologia $2000 \mathbf{4 3}$ 438-442.

37 Miyakawa M, Tsushima T, Murakami H, Isozaki O \& Takano K. Serum leptin levels and bioelectrical impedance assessment of body composition in patients with Graves' disease and hypothyroidism. Endocrine Journal $1999 \mathbf{4 6} 665-673$.

38 Ceccarini G, Flavell RR, Butelman ER, Synan M, Willnow TE, Bar-Dagan M, Goldsmith SJ, Kreek MJ, Kothari P, Vallabhajosula S, Muir TW \& Friedman JM. PET imaging of leptin biodistribution and metabolism in rodents and primates. Cell Metabolism 200910 148-159.

39 Bartalena L, Wiersinga WM \& Pinchera A. Graves' ophthalmopathy: state of the art and perspectives. Journal of Endocrinological Investigation 200927 295-301.

40 Bell A, Gagnon A, Grunder L, Parikh SJ, Smith TJ \& Sorisky A. Functional TSH receptor in human abdominal preadipocytes and orbital fibroblasts. American Journal of Physiology. Cell Physiology 2000279 C335-C340.

41 Agretti P, De Marco G, De Servi M, Marcocci C, Vitti P, Pinchera A $\&$ Tonacchera M. Evidence for protein and mRNA TSHr expression in fibroblasts from patients with thyroid-associated ophthalmopathy (TAO) after adipocytic differentiation. European Journal of Endocrinology 2005152 777-784.

Received 6 April 2010

Accepted 14 April 2010 